\title{
A novel antimicrobial lectin from Eugenia malaccensis that stimulates cutaneous healing in mice model
}

\author{
V. P. Brustein • F. V. Souza-Araújo • A. F. M. Vaz $\cdot$ R. V. S. Araújo $•$ \\ P. M. G. Paiva $\cdot$ L. C. B. B. Coelho $\cdot$ A. M. A. Carneiro-Leão • \\ J. A. Teixeira $\cdot$ M. G. Carneiro-da-Cunha $\cdot$ M. T. S. Correia
}

Received: 29 September 2011 / Accepted: 20 December 2011/Published online: 20 January 2012

(C) Springer Basel AG 2012

\begin{abstract}
Objective The present work reports the purification and partial characterization of an antibacterial lectin (EmaL) obtained from Eugenia malaccensis seeds as well as the evaluation of its effect in the daily topical treatment of repairing process of cutaneous wounds in mice.

Materials and methods The cutaneous wound was produced by the incision of the skin and use of lectin in the treatment of mice cutaneous wounds was evaluated. Surgical wounds were treated daily with a topical administration of EmaL and parameters such as edema, hyperemia, scab, granulation and scar tissues as well as contraction of wounds were analyzed.

Results A novel lectin, with a molecular mass of $14 \mathrm{kDa}$, was isolated from E. malaccensis using affinity chromatography. The lectin (EmaL) agglutinated glutaraldehydetreated rabbit and human erythrocytes; the lectin-induced rabbit erythrocyte agglutination was inhibited by glucose,
\end{abstract}

V. P. Brustein · F. V. Souza-Araújo · A. F. M. Vaz .

P. M. G. Paiva - L. C. B. B. Coelho ·

M. G. Carneiro-da-Cunha - M. T. S. Correia $(\bowtie)$

Departament of Biochemistry, Universidade Federal de Pernambuco (UFPE), Recife, PE 50670-420, Brazil

e-mail: terezacorreia.ufpe@gmail.com

R. V. S. Araújo · M. G. Carneiro-da-Cunha

Laboratory of Immunopathology Keizo Asami,

Universidade Federal de Pernambuco, Recife, PE, Brazil

A. M. A. Carneiro-Leão

Department of Animal Morphology and Physiology,

Universidade Federal Rural de Pernambuco, Recife, Brazil

\section{J. A. Teixeira}

Institute for Biotechnology and Bioengineering,

Centre for Biological Engineering, Universidade do Minho,

Campus de Gualtar, Braga, Portugal casein, ovalbumin and fetuin. Also, Emal was very effective in the inhibition of bacterial growth, with the best inhibition results obtained for Staphylococcus aureus. Inflammatory signals such as edema and hyperemia were statistically less intense when EmaL was applied compared to the control. The histopathological analysis showed that the treated injured tissue presented reepithelialization (complete or partial) and areas of transition more evidenced than those of the control group, especially due to well organized pattern of collagen fibers presented in the granulation fibrous tissue.

Conclusion Presented results are a preliminary indication of the pharmacological interest in using EmaL as antimicrobial agent and in the repairing process of cutaneous wounds.

Keywords Eugenia malaccensis · Lectin · Antibacterial · Cutaneous wound healing

\section{Introduction}

Lectins constitute a heterogeneous group of non-immune protein, structurally distinct with two or more specific binding sites to mono or oligosaccharides (Barondes 1988). They are purified from different species (Sharon and Lis 2004) and in plants they are mainly obtained from legume seeds (Konozy et al. 2003). They have attracted great interest because of their various biological activities (Peumans and Van Damme 1998), in particular, the interactions of plant lectins with human pathogenic bacteria (Slifkin and Doyle 1990). Lectins demonstrated the binding capacity to a wide variety of complex carbohydrates such as teichoic acid, teichuronic acids, peptidoglycans and lipopolysaccharides present in cell walls (Pistole 1981; 
Sharon and Lis 1990; Ratanapo et al. 2001; Gaidamashvili and Standen 2002).

The cutaneous injuries normally heal in a commanded and efficient way, this process being divided in the following phases: hemostasis, inflammatory phase, proliferation phase or granulation and remodeling of the extracellular matrix (ECM) or maturation (Singer and Clark 1999; Clark 2001; Branski et al. 2005; Laurens et al. 2006). It is important to emphasize that significant variations in the nature, composition and duration of these phases in different wounds can occur, depending on the location of the tissue, degree of contamination and bacterial infection, sanguine irrigation and extension of the injury to the tissue (Singer and Clark 1999). The secondary infections of skin are frequently caused by the transitory flora, composed mainly of Staphylococcus aureus or Streptococcus pyogenes. The infection compromises the reepithelialization and increases collagen deposition (Singer and Mcclain 2002; Inngjerdinger et al. 2004).

According to Spector (2001), biomaterials can be used in the rehabilitation of injuries. Biomaterials are defined as any molecule that has the capacity to interact with the biological system without inducing an adverse response in the host as has been observed for Cramoll, a glucose/ mannose lectin that was effective in the repair of experimental lesions in healthy and immunocompromised mice (De Melo et al. 2011).

Eugenia malaccensis L. (Angiospermae division, Myrtaceae family) popularly known in Brazil as jambo is considered a medicinal plant, mainly used by the populations with low purchasing power (Morton and Malay 1987; Whistler 1992; Locher et al. 1995, 1996). The present work reports the purification and partial characterization of an antibacterial lectin (EmaL) obtained from E. malaccensis seeds as well as the evaluation of its effect in the daily topical treatment of repairing process of cutaneous wounds in mice.

\section{Materials and methods}

Lectin purification and characterization

The lectin was purified from a 10\% (w/v) seed extract in $0.15 \mathrm{M} \mathrm{NaCl}$ aqueous solution (crude extract, CE). Following extraction, proteins were precipitated using 0-80\% ammonium sulphate fractionation (F0-80) and the precipitate was further purified by affinity chromatography in Sephadex G-50 column. The column was equilibrated and developed with $0.15 \mathrm{M} \mathrm{NaCl}$ at $10 \mathrm{ml} / \mathrm{h}$ and bound proteins were bio-specifically eluted using $0.3 \mathrm{M}$ glucose in $0.15 \mathrm{M} \mathrm{NaCl}$. A final dialysis step was done and a Eugenia lectin purified fraction, from now on called Emal, was obtained. Protein concentration was measured according to Lowry et al. (1951) and all samples were stored at $-20^{\circ} \mathrm{C}$. Haemagglutinating activity (HA) was evaluated using human (A, B, O and $\mathrm{AB}$ types) and rabbit fresh erythrocytes treated with glutaraldehyde as described by Correia and Coelho (1995).

\section{Effect of $\mathrm{pH}$ on haemagglutinating activity}

The effect of $\mathrm{pH}$ on HA was evaluated by incubating $1 \mathrm{ml}$ EmaL samples $(200 \mu \mathrm{g} / \mathrm{ml})$ at different $\mathrm{pH}$ values for $1 \mathrm{~h}$ at room temperature $\left(25^{\circ} \mathrm{C}\right)$ in $1 \mathrm{ml}$ of selected buffers (0.01 M citrate phosphate buffer, $\mathrm{pH} 2-7$ and $0.01 \mathrm{M}$ Tris$\mathrm{HCl}$ buffer, $\mathrm{pH} 8-12)$. In all experiments, an aliquot $(50 \mu \mathrm{l})$ of the mixture was distributed in a micro-titer plate well and the HA assay was done (Correia and Coelho 1995).

Polyacrylamide gel electrophoresis (PAGE) of denatured protein

Denatured and reduced samples were evaluated as described by Laemmli (1970). The standard marker proteins were bovine serum albumin (67 kDa), ovalbumin (43 kDa), carbonic anhydrase $(30 \mathrm{kDa})$, soybean trypsin inhibition $(20.1 \mathrm{kDa})$ and $\alpha$-lactalbumin $(14.4 \mathrm{kDa})$, purchased from Pharmacia Fine Chemicals (Pharmacia Biotechnology, Uppsala, Sweden). Silver staining of the gel was done according to Merril et al. (1981).

\section{Antibacterial activity assay}

Antibacterial activity of EmaL was investigated by the disc diffusion method (Bauer et al. 1966). $100 \mathrm{ml}$ of warm NA (at $43^{\circ} \mathrm{C}$ ) and $0.5 \mathrm{ml}$ of bacteria suspension $\left(10^{5}-10^{6} \mathrm{CFU} / \mathrm{ml}\right)$ were mixed and $10 \mathrm{ml}$ volumes were distributed in sterile Petri plates $(90 \times 15 \mathrm{~mm})$ and allowed to solidify. Then, 6-mm diameter sterile paper discs were impregnated with $15 \mu \mathrm{l}$ of sterile EmaL solution $(200 \mu \mathrm{g} / \mathrm{ml})$ in $0.15 \mathrm{M} \mathrm{NaCl}$ and placed on the agar surface; also, negative control and positive control discs containing $0.15 \mathrm{M} \mathrm{NaCl}$ and amoxicillin $(1 \mathrm{mg} / \mathrm{ml})$, respectively, were used. Plates were incubated at $37^{\circ} \mathrm{C}$ for $24 \mathrm{~h}$.

Minimal inhibitory concentration (MIC) and minimal bactericide concentration (MBC)

Serial dilutions of EmaL in $\mathrm{NaCl} 0.15 \mathrm{M}$ added to NB containing $10^{7}$ cells $/ \mathrm{ml}$ in the exponential growth phase were used to determine the lectin MIC, according to Courvalin et al. (1985). A serial of ten assay tubes $(13 \times 100 \mathrm{~mm})$ containing $1.8 \mathrm{ml}$ of NB and $0.2 \mathrm{ml}$ of a $1.5 \times 10^{8} \mathrm{CFU} / \mathrm{ml}$ bacterial suspension was prepared. Lectin solution $(1.5 \mathrm{mg} / \mathrm{ml})$ was added to the first tube, 
resulting in a final lectin concentration of $150 \mu \mathrm{g} / \mathrm{ml}$. After homogenization, successive dilutions were performed. Samples were incubated for $24 \mathrm{~h}$ at $37^{\circ} \mathrm{C}$. The control tube contained NB medium and the test microorganism. MIC corresponded to the minimum lectin concentration that inhibited visible bacterial growth.

Minimum bactericidal concentration (MBC) determination was carried out with the tubes obtained in the MIC assay. Dilutions $(1: 10,000)$ of the content of each tube were done and aliquots $(10 \mu \mathrm{l})$ were removed and inoculated in Petri plates containing NA medium. The readings were made by counting the number of $\mathrm{CFU}$. The minimum bactericidal concentration corresponded to the minimum concentration of the lectin that reduced the number of $\mathrm{CFU}$ to $0.1 \%$ of the initial concentration (Courvalin et al. 1985).

\section{Surgical protocol and experimental groups}

Adult females albino Swiss mice (30) were used (age 35-45 days, weight $25 \pm 2 \mathrm{~g}$ ), from the Bioterium of the Laboratory of Imunopatologia Keizo Asami (LIKA), University Federal Pernambuco (UFPE). All mice were treated and killed in accordance with the Ethical Committee of Universidade Federal Rural de Pernambuco for Experiments with Laboratory Animals (Ministry of Health, Brazil, 012/02). Each animal was maintained in an individual cage, with water and commercial food available ad libitum $\left(\right.$ Labina $\left.^{\circledR}\right)$. After hydric and alimentary jejune of $12 \mathrm{~h}$, the animals were weighed and intraperitoneally anesthetized with $2 \%$ xylazine chloridate $(10 \mathrm{mg} / \mathrm{kg})$ and $10 \%$ ketamine chloridate $(115 \mathrm{mg} / \mathrm{kg}$ ) (Hall and Clarke 1991). After anesthesia trichotomy and antisepsis of dorsal thoracic region with $1 \%$ iodopovidone and $70 \%$ ethanol was done. Sterilized cloths of field were located and fixed in the skin of the animal. With the help of a perforated metallic mold (diameter $=1.0 \mathrm{~cm}$ ), the skin was demarcated with a dermographic pen.

The cutaneous wound was made by the incision of the skin with scissors with fine-fine shears of tips and clamp of dissection, until its recession. The hemostasis of the area, when necessary, was carried out by digital compression. The animals were divided into two groups ( $n=15 /$ group) and the wounds were daily treated with $100 \mu \mathrm{l}$ of EmaL (100 $\mu \mathrm{g} / \mathrm{ml})$.

\section{Clinical evaluation and contraction of wounds}

The clinical characteristics of experimental wounds were evaluated every $24 \mathrm{~h}$ after surgery (AS), taking into consideration the following aspects: edema, hyperemia, secretion, bleeding, crust formation, granulation and scar tissue formation. Daily, the measurement of wound areas was calculated, starting from the borders of wounds, using the equation: $A=\pi \operatorname{Rr}(A=$ wound area; $R$ and $r$ the larger and smaller radii of wound, respectively). The calculation of the contraction degree was expressed in percentage using the equations proposed by Ramsey (1995), $100 \times\left(W_{0}-W_{i}\right) / W_{0}=M \pm \operatorname{SE}\left(W_{0}=\right.$ initial area of the wound; $W_{i}=$ area of the wound on the day of the biopsy; $M=$ average; $\mathrm{SE}=$ stand error).

\section{Histopathological analysis}

On the 2nd, 7 th and 12 th days after surgery wound biopsies were accomplished ( $n=5$ /group). After anesthesia, as previously described, samples (fragments of the transition area between complete and wounded skin and wounded skin) were collected. Immediately after the withdrawal of the skin, the samples were placed on a filter paper and settled in formaldehyde $4 \%(\mathrm{v} / \mathrm{v})$ prepared in PBS $0.01 \mathrm{M}$ pH 7.2 and submitted to the histopathology procedures. Each fragment of skin was dehydrated in increasing concentrations of ethanol, dehydration in xylol and unblocked in paraffin. After microtomy $(5 \mu \mathrm{m})$, the slices were stained with trichromic of Masson.

\section{Statistical analysis}

Statistical analysis of the data was done with the software Statistic 6.0. The homoscedasticity of the variance was verified trough the Levene's test. Then, aiming to determine if the area of contraction of the lesion was significantly different among the days of analysis, analysis of variances (one-way Anova) was applied. The Tukey test was utilized to evaluate significant differences between groups. Furthermore, the Chi-square test was applied to evaluate possible significant differences in other clinic characteristics such as: edema, hyperemia, first and second crust formation, granulation and scar tissue. For the tests and analysis, the level of significance adopted to reject the (H0) was $5 \%(\alpha=0.05)$.

\section{Results}

Purification and partial characterization of EmaL

The purification of the E. malaccensis lectin F0-80 fraction by affinity chromatography showed a protein peak biospecifically eluted using $0.3 \mathrm{M}$ glucose (Fig. 1a). The application of ammonium sulphate precipitation followed by affinity chromatography allowed for obtention of a lectin with a high specific activity (Table 1). Under denaturing and reducing conditions EmaL showed only one polypeptide band with molecular mass of approximately 
$14 \mathrm{kDa}$ (Fig. 1b). EmaL agglutinated both rabbit and human ( $\mathrm{A}, \mathrm{B}, \mathrm{AB}$ and $\mathrm{O}$ ) erythrocytes, although agglutination was more intense with the rabbit erythrocytes. For this reason, rabbit erythrocytes were chosen for the subsequent assays. The determination of Emal HA in the presence of different buffers, showed that the highest activity was obtained at $\mathrm{pH} 2.0$ and that a gradual decrease occurred till pH 6.0 (Fig. 1c). The HA reduction or inactivation by $\mathrm{pH}$ was irreversible.
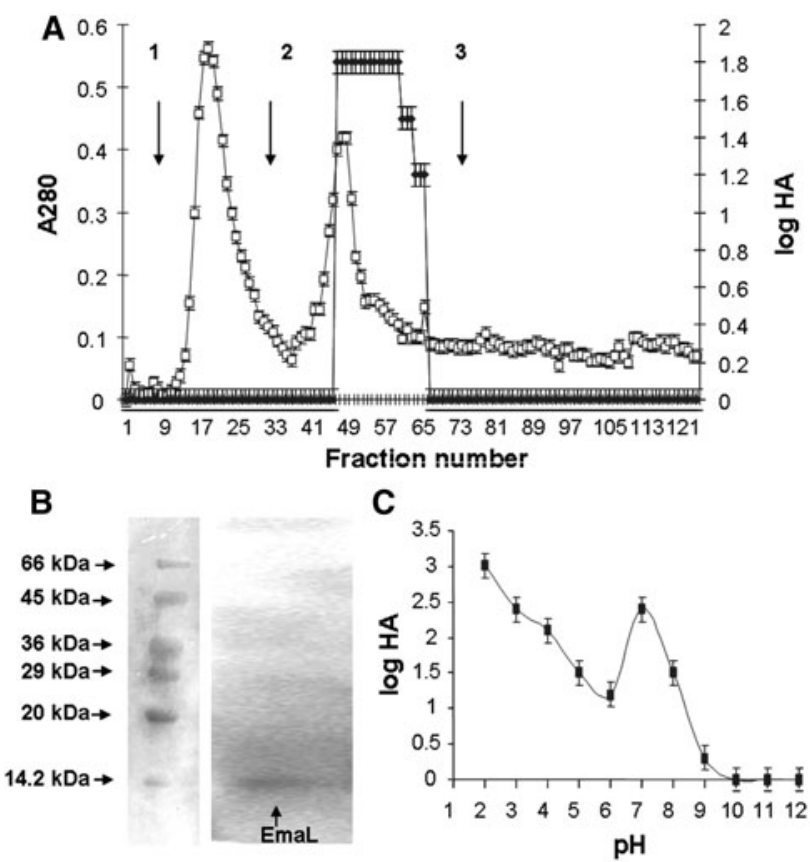

Fig. 1 Purification and partial characterization of EmaL by: a affinity chromatography in Sephadex G-50. Arrows indicated elution with $0.15 \mathrm{M} \mathrm{NaCl}$ (1), followed by $0.3 \mathrm{M}$ glucose in $0.15 \mathrm{M} \mathrm{NaCl}$ (2) and $1 \mathrm{M} \mathrm{NaCl}$ (3). Absorbance at $280 \mathrm{~nm}$ (open squares); log of HA (filled circles). b EmaL SDS-PAGE. $\mathbf{c}$ Influence of the $\mathrm{pH}$ on EmaL haemagglutinating activity. Log HA of EmaL in $0.15 \mathrm{M} \mathrm{NaCl}$ with rabbit erythrocytes was 2.7. Each bar represents the mean $\pm \mathrm{SD}$ of three experiments

Table 1 Overview of the effectiveness of the process for the purification of Emal

\begin{tabular}{lccrl}
\hline Sample & $\begin{array}{l}\text { Volume } \\
(\mathrm{ml})\end{array}$ & $\begin{array}{l}\text { Total protein } \\
(\mathrm{mg})\end{array}$ & \multicolumn{1}{l}{ SHA } & $\begin{array}{l}\text { Purification } \\
\text { factor }\end{array}$ \\
\hline Crude extract & 200 & $2,208.0$ & 92.7 & 1 \\
F0-80 & 15 & 54.0 & 142.2 & 1.5 \\
(EmaL) & 10 & 0.3 & $2,133.3$ & $15^{\mathrm{a}}$ \\
\hline
\end{tabular}

The protein was measured according to Lowry et al. (1951)

$H A$ haemagglutinating activity was made with $2.5 \%$ (v/v) suspension of glutaraldehyde-treated rabbit erythrocytes, $S H A$ specific $\mathrm{HA}=\mathrm{HA} /$ $(\mathrm{mg} \mathrm{ml})$ of protein

${ }^{\text {a }}$ In relation to F0-80 (5 ml) applied in Sephadex G-50 column
Antibacterial activity

EmaL $(200 \mu \mathrm{g} / \mathrm{ml})$ exhibited an antibacterial action as shown in Table 2. The MIC and MBC values are summarized in Table 3.

\section{Wound repair}

During the inflammatory period the presence of edema was observed in all groups. This clinical signal remained until the sixth day after surgery in the group of EmaL and in the control group until the eighth day. On the sixth day after surgery no hyperemia was observed in the Emal-treated animals, while $11.11 \%$ of the animals of the control group were still presenting this flogistic signal (Fig. 2a, b). The first crust in the first day was observed only in the group treated with EmaL (33.3\% of the animals). Between the 3rd to 5th and the 7th to 9th days after surgery, $100 \%$ of EmaL animals group presented the first crust, situation that did not occur in the control group. The second crust formed when the first crust is complete or partially unfastened and

Table 2 Antimicrobial activity of Emal on different bacterial strains, in vitro

\begin{tabular}{ll}
\hline Microorganism & Inhibition halo (mm) \\
\hline Staphylococcus aureus $(+)$ & $26.50 \pm 1.2$ \\
Streptococcus sp. $(+)$ & $23.00 \pm 0.8$ \\
Bacillus sp. $(+)$ & $13.00 \pm 0.8$ \\
Escherichia coli $(-)$ & $19.70 \pm 0.9$ \\
Corynebacterium sp. $(-)$ & $13.75 \pm 0.5$ \\
Klebsiella sp. $(-)$ & $12.75 \pm 0.9$ \\
Pseudomonas aeruginosa $(-)$ & $12.00 \pm 1.4$
\end{tabular}

Values are mean of four assays

(+) Gram-positive bacteria, (-) Gram-negative bacteria

Table 3 MIC and MBC of EmaL against several bacteria

\begin{tabular}{lcc}
\hline Microorganism & MIC $(\mu \mathrm{g} / \mathrm{ml})$ & MBC $(\mu \mathrm{g} / \mathrm{ml})$ \\
\hline Staphylococcus aureus $(+)$ & 1.5 & 15 \\
Streptococcus sp. $(+)$ & 1.5 & 15 \\
Bacillus sp. $(+)$ & 15 & 150 \\
Klebsiella sp. $(-)$ & 15 & 150 \\
Pseudomonas aeruginosa $(-)$ & 15 & 150 \\
Corynebacterium sp. $(-)$ & 15 & 150 \\
Escherichia coli $(-)$ & 15 & 150 \\
\hline
\end{tabular}

Lectin initial concentration was $1.5 \mathrm{mg} / \mathrm{ml}$. MIC corresponds to the minimum lectin concentration capable of inhibiting the visible growth of microorganism. $\mathrm{MBC}$ is the low bactericidal concentration corresponds to the minimum concentration of the lectin capable to reduce the number of $\mathrm{CFU}$ to $0.1 \%$ from the initial inoculum

(+) Gram-positive bacteria, (-) Gram-negative bacteria 
with the presence of remaining exudation in the injured tissue enough to dry up, was identified macroscopically after the seventh day in both groups (Fig. 2a, b).

After the inflammatory phase appears the granulation tissue, that grows to fill the cutaneous imperfection through a neovascularization, filled later, in principle, by type III collagen. The presence of the granulation tissue was observed between the fifth and seventh days after surgery in both groups (Fig. 3a, b) and the peak in the EmaL group was obtained on the seventh day after surgery. The evolution of the injured areas and related contraction averages is illustrated in Fig. 4. The microscopic evaluation of the healing process was followed by the crust presence, infiltrated inflammatory cells, angiogenesis, granulation tissue and reepithelialization of lesion is illustrated in Fig. 5. On the second day after surgery the group treated with EmaL presented a better defined transition area between the complete skin and the injury than the control group (Fig. 4a, b). However, it is important to point out that in the group treated with EmaL the presence of infiltrated inflammatory was more intense and occurred the presence of collagen fibers (Fig. 5a, b).

Figure $5 c, d$ demonstrates the microscopic views of the injuries on the seventh day after surgery. The transition areas of the injuries of the group treated with the EmaL were characterized for presenting a more extensive reepithelialization towards the center of the injury, supported by a fibrovascular granulation tissue. During the 12th day after
Fig. 2 Variation with time of clinical signals after the topic treatment with lectin from Eugenia malaccensis (a) and $0.15 \mathrm{M} \mathrm{NaCl}$ (b)
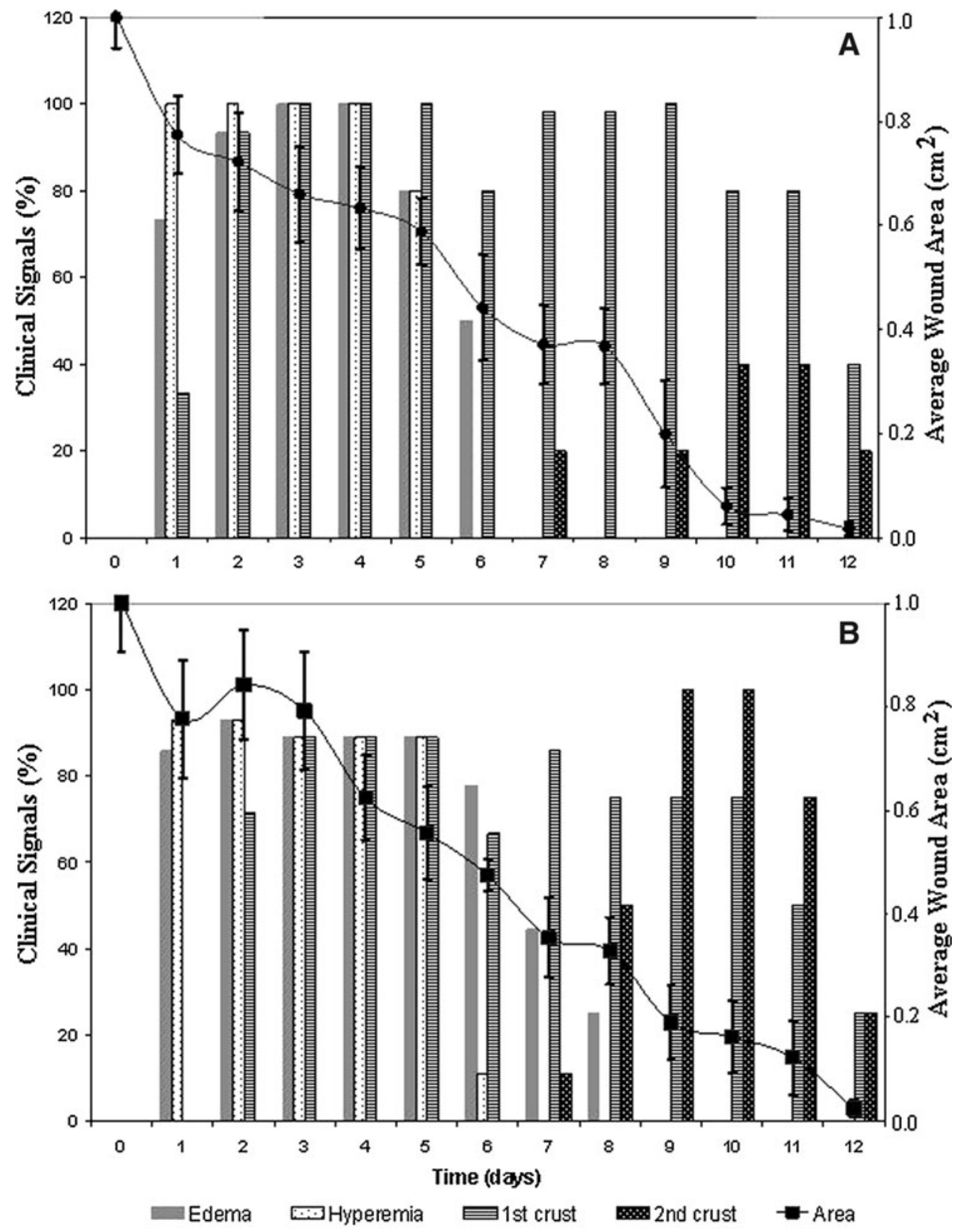
surgery, when the last biopsy was made, the reepithelialization was complete or partial in the studied groups. Macroscopically, the scar was present in three animals, in both groups of a total of $n=5 /$ group (Fig. $4 \mathrm{~d}$, e). With
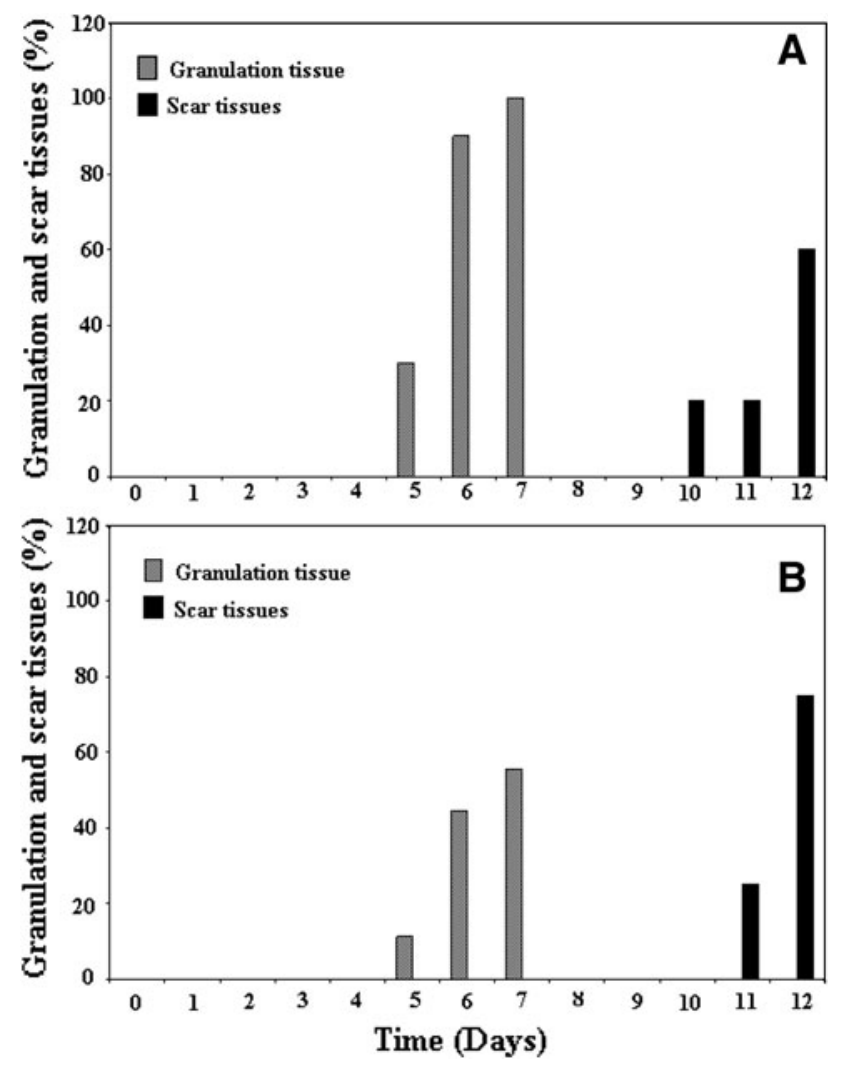

Fig. 3 Granulation and scar tissue variation with time after the topic treatment with lectin from Eugenia malaccensis (a) and $\mathrm{NaCl} 0.15 \mathrm{M}(\mathbf{b})$ respect to the group treated with EmaL, the transition areas were well organized, however, difficult to visualize due to the progression of the phenomenon. Moreover, the granulation tissue was fibrous (rich in collagen), presenting some small vessels (Fig. 5f). With respect to the control group, only the presence of granulation tissue with fibrovascular and vascular characteristics was observed in the animals (Fig. 5e).

\section{Discussion}

As affinity chromatography in lectin purification is mainly based on the protein's ability to bind carbohydrates in a specific and reversible way, and thus, Sephadex G-50 column was used to purify EmaL. Similar results in yield of purified protein were obtained with Concanavalin A (Con A), a lectin obtained from Canavalla ensiformis seeds and a iso-lectin from Cratylia mollis seeds (Correia and Coelho 1995; Agrawal and Goldstein 1967). A great variability of lectin activities has been observed in relation to $\mathrm{pH}$ variations. Erythrina speciosa seeds lectin (EspecL) rapidly lost their activity at all $\mathrm{pH}$ values below $\mathrm{pH} 6.0$, while maintaining the HA virtually unaltered from $\mathrm{pH} 6.5$ to $\mathrm{pH} 9.6$ (Konozy et al. 2003).

Emal lectin proved to be more effective against $S$. aureus and the Streptococcus sp., as concluded from the corresponding MIC and MBC values. Nevertheless, the fact that agglutinins were mostly isolated from storage parts of plants, also suggests their possible contribution to plant defense mechanisms (Gaidamashvili and Standen 2002).
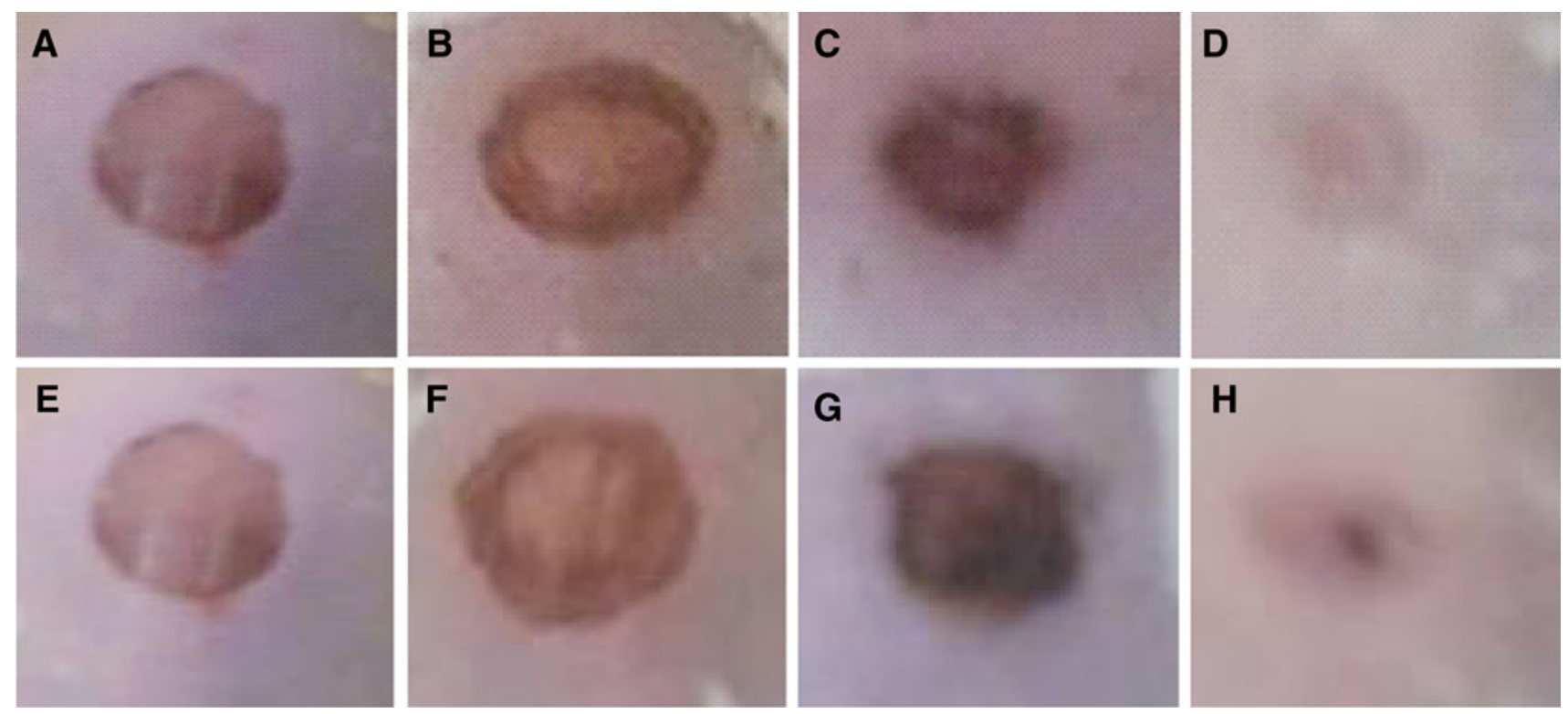

Fig. 4 Macroscopic aspects of the experimental wound. Day of surgery: a group EmaL; e $0.15 \mathrm{M} \mathrm{NaCl}$. Second day after surgery: b group EmaL; f $0.15 \mathrm{M} \mathrm{NaCl}$. Seven days after surgery: c group EmaL; g $0.15 \mathrm{M} \mathrm{NaCl}$. 12 days after surgery: d group EmaL; h $0.15 \mathrm{M} \mathrm{NaCl}$ 

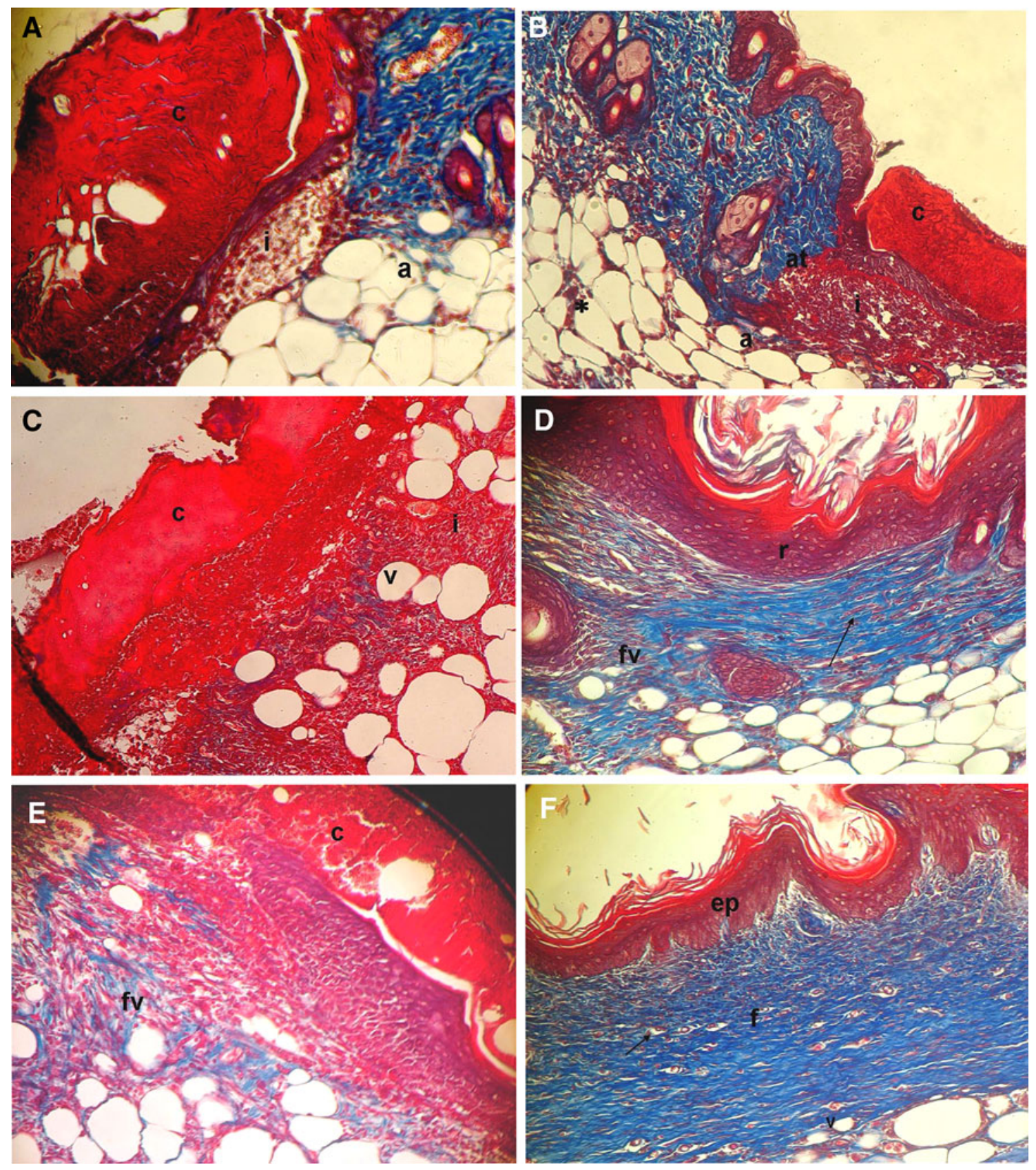

Fig. 5 Histopathological views of the cutaneous wounds. Second day after surgery: a $0.15 \mathrm{M} \mathrm{NaCl}$; b EmaL. Seventh day after surgery: c $0.15 \mathrm{M} \mathrm{NaCl}$; d EmaL. 12th day after surgery: e $0.15 \mathrm{M} \mathrm{NaCl}$;

f EmaL. $c$ crust, $i$ infiltrated inflammatory, at area of transition,

Vegetal lectins, especially the ones that are homologous to Con A (glucose-mannose) are capable of modulating the conscription of neutrophils by indirect mechanisms (Alencar et al. 2003, 2005; Assreuy et al. 2003; Maciel et al. 2004). Dubois et al. (1998) demonstrated the capacity of the stimulant effect of the ConA for the production of metalloproteinase-9 (MMP-9). According to Nagase et al. (2006) this MMP-9 participates in the phenomenon of wound healing, being responsible together with MMP-2 for

$a$ angiogenesis, arrow fibroblast, asterisk collagenous fibers, $v$ vascular granulation tissue, $r$ reepithelialization, $f v$ fibrovascular granulation tissue, $e p$ epidermis, $f$ fibrous granulation tissue. Trichromic of Masson $(\times 100)$

metabolizing elastin, collagen type IV and other molecules of the ECM. It is known that lectins are chemoattracted by the inflammatory cells and, consequently, stimulate synthesis and secretion of several cytokines involved in the wound healing process (Sell and Costa 2003).

In summary, the results demonstrated that EmaL had a potent antibacterial activity with in vitro growth inhibition of some important pathogenic bacteria and could be used in the process of cutaneous wounds repair. Future research on 
the applications of lectins obtained from medicinal plants, in biological systems, can be of great importance for clinical microbiology and therapeutic treatments.

Acknowledgments This paper was financially supported by the Conselho Nacional de Desenvolvimento Científico e Tecnológico (CNPq), FACEPE and CAPES, Brazil. The authors are deeply grateful for the technical assistance of Maria Barbosa Reis da Silva and João Antonio Virgínio and Alfa/VALNATURA Project.

Conflict of interest The authors declare that they have no conflict of interest.

\section{References}

Agrawal BBL, Goldstein IJ (1967) Protein carbohydrate interaction. VI. Isolation of concanavalin A by specific adsorption on crosslinked dextran gels. Biochim Biophys Acta 147:262-271

Alencar NMN, Assreuy AMS, Alencar VBM et al (2003) The galactose-binding lectin from Vatairea macrocarpa seeds induces in vivo neutrophil migration by indirect mechanism. Int J Biochem Cell Biol 35:1674-1681

Alencar VBM, Alencar MNN, Assreuy AMS et al (2005) Proinflammatory effect of Arum maculatum lectin and role of resident cells. Int J Biochem Cell Biol 37:1805-1814

Assreuy AM, Alencar NMN, Cavada BS et al (2003) Porcine spermadhesin PSP-I/PSP-II stimulates macrophages to release a neutrophil chemotactic substance: modulation by mast cells. Biol Reprod 68:1836-1841

Barondes SH (1988) Bifunctional properties of lectins: lectins redefined. Trends Biochem Sci 13:480-482

Bauer AW, Kirby WMM, Sherres JC et al (1966) Antibiotic susceptibility testing by a standardised single disc method. Am J Clin Pathol 45:493-496

Branski RC, Rosen CA, Verdoline K, Hebda PA (2005) Biochemical markers associated with acute vocal fold wound healing: a rabbit model. J Voice 19:283-289

Clark RAF (2001) Fibrin and wound healing. Ann NY Acad Sci 936:355-367

Correia MTS, Coelho LCBB (1995) Purification of a glucose/ mannose specific lectin, isoform 1, from seeds of Cratylia mollis Mart. (Camaratu bean). Appl Biochem Biotechnol 55:261-273

Courvalin P, Goldstein F, Philippon A, Sirot J (1985) L'antibiogramme MPC. Vigot, Bruxelles, pp 191-195

De Melo CM, Porto CS, Melo-Júnior MR et al (2011) Healing activity induced by Cramoll 1,4 lectin in healthy and immunocompromised mice. Int J Pharm 15:113-119

Dubois B, Peumans WJ, Van Damme EJM et al (1998) Regulation of gelatinase B (MMP-9) in leukocytes by plant lectins. FEBS Lett 427:275-278

Gaidamashvili M, Standen JV (2002) Interaction of lectin-like proteins of South African medicinal plants with Staphylococcus aureus and Bacillus subtilis. J Ethnopharmacol 80:131-135

Hall LW, Clarke KW (1991) Veterinary anaesthesia, 9th edn. Ballière Tindall, London
Inngjerdinger K, Nergard CS, Diallo D et al (2004) An ethnopharmacological survey of plants used for wound healing in Dongoland, Mali. West Africa J Ethnopharm 92:233-244

Konozy EHE, Bernardes ES, Rosa C et al (2003) Isolation, purification, and physicochemical characterization of a D-galactose-binding lectin from seeds of Erythrina speciosa. Arch Biochem Biophys 410:222-229

Laemmli UK (1970) Cleavage of structural protein during the assembly of the head of bacteriophage T4. Nature 227:680-685

Laurens N, Koolwijk P, De Maat MPM (2006) Fibrin structure and wound healing. J Thromb Haem 4:932-939

Locher CP, Burch MT, Mower HF et al (1995) Anti-microbial activity and anti-complement activity of extracts obtained from selected Hawaiian medicinal plants. J Ethnopharmacol 49:23-32

Locher CP, Witvrouw M, De Bethune MP et al (1996) Antiviral activity of Hawaiian medicinal plants against human immunodeficiency virus type-1 (HIV-1). Phytomedicine 2:259-264

Lowry OH, Rosebrough NJ, Farr AL et al (1951) Protein measurement with the Folin phenol reagent. J Biol Chem 193:265-275

Maciel EVM, Araujo-Filho VS, Nakazawa M et al (2004) Mitogenic activity of Cratylia mollis lectin on human lymphocytes. Biologicals 32:57-60

Merril CR, Goldman D, Sedman AS et al (1981) Ultrasensitive stain for proteins in polyacrylamide gels shows regional variation in cerebrospinal fluid proteins. Science 211:1437-1438

Morton J, Malay A (1987) Fruits of warm climates. Julia F. Morton, Miami, pp 378-381

Nagase H, Visse R, Murphy G (2006) Structure and function of matrix metalloproteinases and TIMPs. Cardiovasc Res 69: $562-573$

Peumans WJ, Van Damme EJM (1998) Plant lectins versatile proteins with important perspectives in biotechnology. Biotechnol Genet Eng Rev 15:199-228

Pistole TG (1981) Interaction of bacteria and fungi with lectins and lectin-like substances. Annu Rev Microbiol 35:85-112

Ramsey D (1995) Effects of three occlusive dressing materials on healing of full-thickness skin wounds in dogs. Am J Vet Res 56:941-949

Ratanapo S, Ngamjunyaporn W, Chulavatnatol M (2001) Interaction of a mulberry leaf lectin with a phytopathogenic bacterium, P. syringae pv mori. Plant Sci 160:739-744

Sell AM, Costa CP (2003) Effects of plant lectins on in vitro fibroblast proliferation. Braz Arch Biol Technol 46:349-354

Sharon N, Lis H (1990) Legum lectins, a large family of homologous proteins. Faseb J 4:3198-3208

Sharon N, Lis H (2004) History of lectins: from hemagglutinins to biological recognition molecules. Glycobiology 14:53-62

Singer AJ, Clark RAF (1999) Cutaneous wound healing. N Engl J Med 341:738-746

Singer AJ, Mcclain A (2002) Persistent wound infection delays epidermal maturation and increases scarring in thermal burns. Wound Repair Regen 10:372-377

Slifkin M, Doyle RJ (1990) Lectins and their application in clinical microbiology. Clin Microbiol Rev 3:197-218

Spector M (2001) Biomaterials. In: Achauer B, Eriksson E, Guyuron B (eds) Plastic surgery, indications, operations, outcomes. Mosby Year Book, pp 239-259

Whistler Polynesian Herbal Medicine (1992) Everbest Publishing Co., Hong Kong 